\title{
"VEJAM BEM". JOSÉ AFONSO, BRECHT Y LA VÍA MODERNA A LA CANÇÃO DE PROTESTO ${ }^{1}$
}

\author{
"VEJAM BEM". JOSÉ AFONSO, BRECHT \\ AND THE MODERN WAY TO THE CANÇÃO DE PROTESTO
}

\author{
César Rodríguez Campos \\ Universidad de Granada \\ cesarguez@gmail.com \\ ORCID ID: 0000-0001-6573-5196
}

\section{Resumen}

El encuentro con la obra y pensamiento de Bertolt Brecht puede ser considerado un momento crucial para el desarrollo artístico del cantautor y poeta portugués José Afonso (Aveiro, 2 de agosto de 1929-Setúbal, 23 de febrero de 1987), dibujando un marco creativo que se ampliará a partir de 1967 como contexto teórico y práctico desde el que entender mucha de su producción. En este sentido, José Afonso lleva al terreno musical popular portugués la reivindicación de Brecht como modelo de intervención cultural que impregna la oposición socialista a la dictadura de Salazar. De este modo, es posible identificar tanto en sus ideas como en sus prácticas compositivas e interpretativas una apropiación consciente de las concepciones brechtianas. Esta apropiación se produce no solo en lo que concierne al papel cultural y político del músico y su música en la ruptura del monolítico orden cultural salazarista, sino también en una dimensión intrínsecamente estética, en la propia utilización de voces cronológica y estilísticamente múltiples para ensamblar artefactos de gran poder expresivo y movilizador. En las canciones de José Afonso, particularmente en las que compuso sobre textos de Brecht, están presentes muchos de los principios y procedimientos constructivos que sitúan al dramaturgo en una línea simultáneamente moderna y políticamente comprometida. Especialmente destacable es la transferencia a la música de los métodos de montaje y superposición de lenguajes, lo que se traduce en un juego ambivalente entre lo tradicional y lo urbano para promover una reconstrucción crítica de lo real. Esto permitiría definir su producción como moderna y popular.

${ }^{1}$ El autor desea agradecer muy especialmente la amabilidad y confianza de Rui Pato, guitarrista y amigo de José Afonso, quien facilitó el acceso a la correspondencia de José Afonso con su padre, Albano de Rocha Pato. Agradezco igualmente la infor-

\begin{abstract}
The encounter with Bertolt Brecht's work and thought can be considered a turning point for the artistic development of the Portuguese singer, songwriter, and poet José Afonso (Aveiro, 2 August 1929-Setúbal, 23 February 1987), setting a creative framework, to be expanded since 1967 as a theoretical and practical context in which much of his production can be understood. In this way, José Afonso takes to the field of popular music the vindication of Brecht as a model of cultural intervention by socialist opposition to Salazar's dictatorship. Thus, it is possible to identify a conscious appropriation of Brechtian conceptions reflecting on his ideas as well as on his performance practice. This move not only has to do with the cultural and political role of musician and music aiming to break the monolithic fascist cultural order, but — on an intrinsically aesthetic dimension - with the very use of chronologically and stylistically multiple voices to assemble artifacts of a great expressive and mobilizing power. In José Afonso's songs, particularly in those composed on Brecht's texts, many of the principles and procedures that place the playwright on the modern and politically engaged side alike are present. It is especially remarkable the transfer to music of montage and musical languages interweaving methods. This transfer manifests itself in the ambivalent play between the traditional and the urban, the parodic and the tragic in order to promote a critical reconstruction of reality. Thus, we can characterize his production both as modern and popular.
\end{abstract}

mación aportada en entrevista personal por Vitorino Salomé, amigo y estrecho colaborador musical del cantautor. Los comentarios y sugerencias de José Tito y Gabriel Cabello fueron así mismo muy valiosos. 


\section{Palabras clave}

José Afonso (1929-1987), Bertolt Brecht, música popular portuguesa, canción de intervención, modernidad, estética musical, siglo XX, música grabada.

\section{INTRODUCCIÓN: CULTURA POPULAR, MODERNIDAD E INTERVENCIÓN POLÍTICA. EL USO DE LA MÚSICA POPULAR EN BRECHT}

Es habitual el encuadre de las producciones musicales consideradas "serias" o "cultas" en el seno de las grandes corrientes estéticas del siglo XX. En concreto, existen innumerables estudios sobre el sesgo moderno, impresionista o expresionista de las obras de determinados compositores relevantes, en parangón con adscripciones estilísticas neoclásicas, tradicionalistas o vinculadas al realismo literario de otros, o incluso analizando aspectos divergentes en la producción de un mismo músico. ${ }^{2}$ La música se nos ofrece así compartiendo un espacio de apreciaciones y significaciones comunes con otras manifestaciones culturales dentro de una coyuntura histórica precisa. Mucho menos frecuente es aproximarse a la obra de un autor de música popular desde una perspectiva en la que salga a la luz su cercanía o relación con los movimientos que marcaron el devenir y la fisonomía del arte contemporáneo. ${ }^{3}$ El problema estriba precisamente en la peliaguda cuestión de si atribuimos a la música popular una cualidad "artística" o simplemente la colocamos en un terreno ajeno a lo estético, donde primen su uso funcional como "entretenimiento" o su condición de produc-

2 Sin salirnos de Portugal, ámbito geográfico de nuestro estudio, la obra y pensamiento de Fernando Lopes-Graça han sido caracterizados como modernos repetidamente, mientras que determinados aspectos de su producción generan controversia en relación a su parentesco o no con el neorrealismo. Véanse Teresa Cascudo, "A configuração do modernismo musical em Portugal a través da accção de Fernando Lopes-Graça”, en Fernando Lopes-Graça, ed. Pedro Maia (Porto: Atelier de Composição, 2008), pp. 29-63; y Mário Vieira de Carvalho, "Between Political Engagement and Aesthetic Autonomy: Fernando Lopes-Graça's Dialectical Approach to Music and Politics", Twentieth-Century Music, 8 /2 (2011), pp. 175-202.

${ }^{3}$ Como excepción relevante hay que hacer notar el trabajo de Alexandre Pereira Martins, "Rekonstruktion der Poetik des portugiesischen Dichters und Liedermachers José Afonso (1929-1987)", tesis doctoral, Colonia, Alemania, Universität zu Köln, 2011.

\section{Keywords}

José Afonso (1929-1987), Bertolt Brecht, Portuguese popular music, political song, modernism, musical aesthetics, 20th century, recorded music.

to comercial condicionado por las exigencias del mercado y la identificación y satisfacción de los gustos de audiencias masivas. En este caso, estaríamos encajonando a la música popular en un gueto sociológico al que le serían inaplicables etiquetas como modernidad, experimentación o vanguardia. ${ }^{4}$

El establecer como punto de partida analítico este tipo de división del campo musical solo tiene sentido si no consideramos los dominios musicales como lo que son: construcciones discursivas estrechamente relacionadas con posiciones ideológicas y culturales pertinentes en exclusiva a un corte histórico-social preciso. ${ }^{5}$ Más allá de la confrontación entre autonomía formal y utilidad social,

\footnotetext{
4 No podemos, por razones de espacio, entrar en profundidad en la interminable discusión sobre qué es y qué no es la música popular. Baste decir que, en nuestro enfoque, sumamos a la canónica visión tecnológica anglosajona, formulada por Peter Manuel, una dimensión más amplia que la relaciona con sus inevitables connotaciones ideológicas en una sociedad determinada, concepción desarrollada, entre otros, por Richard Middleton o Stuart Hall. Manuel aplica el término a un tipo de música producida y comercializada como mercancía y transformada estilísticamente por el efecto de los mass media. Excediendo esta visión "objetivista", nos parece crucial defender la "autonomía relativa" de la forma musical popular, y considerar el uso y la posición de tal música en relación a la distribución social e histórica de sus productores y usuarios. Como Middleton, contrarios a cualquier esencialismo, vemos necesario articular la relación entre formas musicales y grupos sociales dentro de las contradicciones que generan los conflictos de poder y la impregnación de las formas hegemónicas de cultura. Lo popular (al igual que lo "artístico") sería así un concepto dinámico en constante elaboración discursiva, determinado por posiciones de dominio y subordinación dentro del campo musical en su conjunto. Véanse Peter Manuel, Cassette Culture: Popular Music and Technology in North India (Chicago: The University of Chicago Press, 1993), p. xvi; Richard Middleton, Studying Popular Music (Philadelphia: Open University Press, 1990, reimpresión de 2002), pp. 3-11; y Stuart Hall, "Notes on Deconstructing the 'Popular'", en Cultural Theory and Popular Culture: A Reader, ed. John Storey (Pearson: Prentice Hall, 1998), pp. 442-53.

5 Salwa Castelo-Branco, "Introducção", en Enciclopédia da Música em Portugal no Século XX, 4 vols., dir. Salwa Castelo-Branco (Lisboa: Círculo de Leitores, 2010), vol. 1, p. v.
} 
desde el momento en que cotidiana o profesionalmente se emiten juicios de valor, los criterios por los que una canción popular se considera cualitativamente diferente de otra aparecen en el discurso. ${ }^{6}$ Dichos criterios son formulados en categorías idénticas a las usadas para valorar el campo "serio" (innovación, coherencia formal, autenticidad, entre otras) o en otras específicas como la tecnificación o la "popularidad". El propio Theodor Adorno, nada sospechoso de simpatía hacia la música popular, llamaba a considerar la escena cultural como un todo superior a la suma de las partes, concediendo a la "dialéctica de lo bajo" el mismo valor que a la "dialéctica de lo alto"?

Frente a la opción de Adorno por un arte moderno de vanguardia para hacer frente a la reificación y mercantilización de la cultura de masas, aparece ya en Antonio Gramsci una actitud positiva hacia las nuevas y renovadoras prácticas culturales que emergían en relación a los grandes cambios en los procesos de producción.

El cambio enorme en los procesos de producción tiene como efecto una nueva cultura, nuevas formas de producción literaria, de recepción, nuevas necesidades y expectativas en las prácticas de la vida diaria. En esto Gramsci reconoce que "lo que es" en cuanto "realista", él lo ha convertido en "modernista", un modernista, sin embargo, que mira a su realidad no desde arriba, sino desde abajo: desde el punto de vista de las personas involucradas en el trabajo y la producción. ${ }^{8}$

6 Simon Frith, "Towards an aesthetic of popular music", en Taking Popular Music Seriously (London: Ashgate, 2007), pp. 257-274; especialmente pp. 257-258.

7 Adorno evidentemente lo hacía no para disolver la antinomia, sino para responder a las afirmaciones de Benjamin sobre la decadencia del gran arte y la pérdida del aura; véase Theodor Adorno, "Carta a Walter Benjamin de 18 marzo 1936", en Aesthetics \& Politics: Debates between Bloch, Lukács, Brecht, Benjamin, Adorno, ed. Ronald Taylor (London: Verso, 1980), pp. 120-26, especialmente p. 123.

${ }^{8}$ Renate Holub, Antonio Gramsci. Beyond Marxism and Postmodernism (Abingdon: Routledge, 2014), p. 102: "The immense changes in the processes of production effect a new culture, new forms of literary production, of reception, new needs and expectations in the practices of everyday life. In this Gramsci acknowledges "what is" Qua 'realist' he has turned 'modernist', a modernist, however, who looks at his reality not from above but from below: from the point of view of the people involved in work and production". Las traducciones al español son del autor.
En este sentido, se está ligando la aparición de una nueva forma moderna de percepción de la realidad a la aparición de productos culturales "populares" diferenciados de la "alta cultura". Lo que existe son productos diferentes que satisfacen necesidades diferentes. El resultado es que se borra la diferencia entre lo "alto" y lo "bajo". La propia emergencia de la cultura popular como instrumento crítico se vuelve así un resultado de los debates progresistas sobre la modernidad. En relación al lugar de la música en estas polémicas existe una disparidad radical: o bien toda la música popular carece de dimensión utópica (Adorno) y es de por sí alienante y sujeta a la manipulación productiva capitalista, o bien es posible modificarla, subvertirla y reconstruirla con el fin de utilizarla libremente al servicio de una estética a la vez moderna y políticamente intervencionista.

Como representante de esta última postura, la figura del dramaturgo alemán Bertolt Brecht adquiere especial relevancia por la manera en que conjuga una modernidad de tipo constructivista o cubista y una subordinación de cualquier innovación formal al propósito último de configurar una consciencia revolucionaria al servicio de las luchas de las clases trabajadoras. ${ }^{10} \mathrm{~A}$ la música, Brecht le asigna un papel determinante en el cuestionamiento de los procedimientos y dispositivos hegemónicos ideológicos y artísticos de transmisión del statu quo social. En especial, la música popular -incluyendo tanto los géneros urbanos alemanes utilizados en el cabaret (jazz, blues y ritmos bailables), como músicas tradicionales de culturas no occidentales - es un recurso de primer orden para recuperar una capacidad narrativa perdida y desenmascarar la naturaleza opresiva de la realidad social. ${ }^{11}$ Mediante una superposición de técnicas vanguardistas de distanciamiento, textos de contenido político radical, ritmos urbanos o paródicos y resonancias melódicas tradicionales, él mismo y los compositores que trabajaron a su lado elaboraron un

9 Holub, Antonio Gramsci, p. 109.

${ }_{10}$ Para un estudio en profundidad de la variante estética de Brecht dentro de la modernidad marxista, véase Eugene Lunn, Marxism \& Modernism. An Historical Study of Lukács, Brecht, Benjamin, and Adorno (Berkeley: University of California Press, 1982), especialmente pp. 121-123, sobre las fuentes específicamente cubistas y constructivistas de la obra brechtiana y la relación con estas de los compositores que utilizó para musicar sus poemas y canciones.

11 Lunn, Marxism \& Modernism, p. 56. 
tipo de música que desafiaba los géneros establecidos; estaba dotado de una capacidad singular de inquietación ideológica y alteración de los esquemas convencionales de escucha.

Nuestro propósito en las páginas que siguen es mostrar cómo en el recorrido musical del cantautor y poeta portugués José Afonso (Aveiro, 2 de agosto de 1929-Setúbal, 23 de febrero de 1987) están presentes desde muy pronto, los principios, procedimientos y objetivos de esta modernidad "activista" brechtiana. Pretendemos subrayar la traslación de los planteamientos que para Brecht eran válidos en la lucha cultural y política contra el fascismo alemán y el capitalismo de los años 30 y 40 del siglo XX a la situación específicamente portuguesa de oposición al salacismo. De forma inevitable, el foco de atención preferente lo constituirán las canciones que Afonso compuso para la representación de La excepción y la regla de Brecht. No obstante, existe una composición angular, "Vejam bem", insertada como banda sonora del corto O Anúncio (1966), dirigido por José Cardoso (1930-2013), que ejemplifica como ninguna la síntesis afonsina de la práctica del montaje musical, la auto-reflexión sobre los medios de mostrar la realidad y la reconstrucción crítica de esta. Examinaremos la interacción que se establece entre los lenguajes de la canción y el cine bajo patrones estilísticos plasmados en términos análogos a los utilizados por Brecht.

En este punto, parece conveniente trazar algunas líneas sucintas que ayuden a comprender la utilidad de las posiciones estéticas de Brecht para situar desarrollos posteriores de la música popular y, muy especialmente, su pertinencia en un análisis de la imbricación de forma moderna (músico-poética) y compromiso político en José Afonso.

En primer lugar, la música es solo uno de los elementos que se incluyen en un concepto más amplio de la cultura popular y de lo popular en su conjunto. Brecht apela a limpiar terminológicamente esta idea de falseamientos ahistóricos: "Uno debe dirigirse al pueblo [...] y hablar su idioma [...] Es en el interés de la gente, de las amplias masas trabajadoras, recibir una imagen fiel de la vida". ${ }^{12}$ Popular significa: "inteligible para las am-

12 Bertolt Brecht, "Popularity and Realism", en Aesthetics \& Politics, pp. 79-85, 80: "One must turn to the people [...] and speak their language. [...] It is in the interest of the people, of the broad working masses, to receive a faithful image of life". Este plias masas, adoptando y enriqueciendo sus formas de expresión / asumiendo su posición, confirmándola y corrigiéndola [...] relacionándolo con las tradiciones y desarrollándolas" ${ }^{13}$ En Brecht existen dos vectores dialécticamente relacionados: uno en dirección al "pueblo", identificar y apropiarse de sus medios de expresión, y otro, de vuelta al artista o al intelectual, una transformación de estos para devolverlos enriquecidos y clarificados pero comprensibles y utilizables. En relación a esta inteligibilidad, Brecht enfatiza la idea de proceso: "No solo existe el hecho de ser popular, está también el proceso de convertirse en popular". ${ }^{14}$ La transformación afecta a la vez a la gente común receptora de los mensajes, desvelando la visión hegemónica de la realidad, y al emisor de los mismos, mimetizándolo con los intereses de aquella. Frente a la idea de una composición elitista en un lenguaje arcano sin conexión social, Brecht sentencia: "Si al menos Adorno entendiera de una vez por todas que la música está hecha por y para el pueblo". ${ }^{15}$

En segundo lugar, los procedimientos de re-construcción de este lenguaje a la vez accesible y transformado son decididamente modernos. La interrupción del discurso lineal y la segmentación perceptiva que introduce el montaje en el cine impregnan una concepción de la representación en la que imágenes de películas o canciones populares son interpoladas en las piezas teatrales para crear un rompecabezas poliédrico de puntos de vista complementarios. ${ }^{16}$ Pero este procedimiento se traslada también al interior de la música misma, esta vez como juego

texto fue escrito originalmente en 1938 para ser publicado en la revista Das Wort, pero no vio la luz hasta la edición póstuma de sus Schriften zur Kunst und Literatur, 3 vols. (Frankfurt: Suhrkamp Verlag, 1967).

13 Brecht, "Popularity and Realism”, p. 81: “...inteligible to the broad masses, adopting and enriching their forms of expression / assuming their standpoint, confirming and correcting it [...] relating to traditions and developing them".

${ }^{14}$ Bertolt Brecht, Arbeitsjournal (9 de mayo 1942); citado en Brecht, Music and Culture. Hanns Eisler in Conversation with Hans Bunge, ed. Sabine Berendse y Paul Clemens (London: Bloomsbury, 2014), p. 15: "There is not only such a thing as being popular, there is also the process of becoming popular".

15 Brecht, Arbeitsjournal (9 de mayo de1942); citado en Berendse y Clemens, Brecht, Music and Culture, p. 15: "If only Adorno would understand once and for all that music is made by people and for people".

16 Lunn, Marxism \& Modernism, pp.103 y 121. 
de articulaciones en las que las diversas y heterogéneas piezas del mecanismo interactúan unas con otras para provocar el efecto de extrañamiento (Verfremdung). ${ }^{17}$ Las canciones de Hanns Eisler, Kurt Weill, Paul Dessau o Franz Bruinier están fabricadas según procedimientos que Adorno vio como "Un estilo-montaje que niega y al mismo tiempo eleva a un nuevo nivel la apariencia superficial del neoclasicismo y yuxtapone y cimenta ruinas y fragmentos unas contra otros". ${ }^{18}$

Una noción brechtiana enfocada más específicamente hacia la música es la de "gesto". Quizás resida aquí una de sus intuiciones más fecundas y practicables para desbrozar determinado tipo de capacidades expresivas en la canción popular (y constatar su inexistencia en otras). El gesto musical presenta dos vertientes, surgidas de un mismo impulso: una vuelta hacia la relación entre música y texto y otra hacia la relación entre el intérprete, la música y lo que comunica. Para que una música sea "gestual" debe poseer la habilidad de fundirse con el texto al servicio de la eficacia narrativa; tiene que ser capaz de recuperar el arte antiguo de contar historias, floreciente en ciertas tradiciones seculares. ${ }^{19}$ Por otra parte, "Un lenguaje es gestual cuando se basa en el gesto; anuncia de-

17 Véase en Lawrence Kramer, Musical Meaning. Toward a Critical History (Berkeley: University of California Press, 2002), pp. 220-43, el análisis que hace del "Moritat von Mackie Messer" de Weill/Brecht en Die Dreigroschenopper. La rigidez mecánica de la repetición estrófica se ve allí contrapuesta a una intensificación de los recursos expresivos producida tanto por el uso irónico y no convencional de los parámetros armónicos y tímbricos como por las vocalizaciones de tipo expresionista de la interpretación. Como consecuencia de la ambigüedad de significación resultante, calificada como "moderna" por Kramer, se produce la posibilidad de un distanciamiento crítico en la escucha.

18 Theodor Adorno, "Zur gesellschaftlichen Lage der $\mathrm{Mu}-$ sik", Zeitschrift für Sozialforschnung (1932), p. 122; citado por Max Paddison, "The Critique Criticised: Adorno and Popular Song", Popular Music, 2 (1982), p. 214-215: "A montage-style, which negates and at the same time raises to a new level [aufhebt] the surface appearance of neo-classicism and juxtaposes and cements ruins and fragments up against one another". Adorno no tiene otra opción que considerar esta clase de música dentro del campo "serio". Como apunta Paddison, el proceso consiste, para él, en incrustar en materiales obsoletos de la tradición burguesa elementos expresivos de la música popular; aparentemente, la inversión de los términos le parecía a Adorno inconcebible.

${ }_{19}$ Berendse y Clemens, Brecht, Music and Culture, p. 56. terminadas actitudes del que habla y que este adopta frente a otras personas". ${ }^{20}$ Más específicamente: "Lo importante [para el músico] es que este principio de fijar la atención en el gesto le permita adoptar una actitud política haciendo música. Para ello es necesario que desarrolle un gesto social". ${ }^{21}$ Lo que Brecht destaca, en consecuencia, no es una simple traducción gestual más o menos distante en el cuerpo del intérprete de los matices emocionales sugeridos por la música; es una actitud integral en la que intérprete y música se cuestionan mutuamente para presentarse ante el público de una manera concreta que "determina su posición en un sistema de relaciones sociales" . ${ }^{22}$ Ironía, astucia, crítica, y no resignación o desesperación devuelven al escenario la humanidad en el arte. ${ }^{23}$

\section{JOSÉ AFONSO Y BRECHT}

Con anterioridad a su partida para Mozambique en 1964, José Afonso ya tenía un conocimiento directo de la obra de Brecht. En una carta dirigida a Albano de Rocha Pato en el verano de ese año le pide lo siguiente:

Diga ao Dr. Paulo Quintela que lhe agradeço o ter-se lembrado de mim para musicar as traduções do Brecht. É uma ideia a que gostaria de lançar-me. Se me sentisse à altura do que pretende o Dr. Paulo Quintela. Gostaria que ele me indicasse uma bibliografia decente sobre o poeta. ${ }^{24}$

Paulo Quintela era, a la sazón, un germanista prestigioso. Las traducciones a que se refiere José Afonso deben guardar relación con la selección de poemas de Brecht que aquel dio a conocer en 1962 en la revista Vértice, publicación ligada al Partido Comunista Portugués y que había venido desempeñando un papel fundamental en la teorización y divulgación del movimiento neorrealista. ${ }^{25}$ Con anterioridad a estas traducciones, tan solo cuatro poemas de Brecht habían visto la luz en el Portugal sala-

20 Bertolt Brecht, Escritos Sobre Teatro (Barcelona: Alba editorial, 2004), p. 240.

${ }^{21}$ Brecht, Escritos Sobre Teatro, p. 241.

22 Brecht. Escritos Sobre Teatro, p. 241.

23 Brecht, Escritos Sobre Teatro, p. 243.

24 José Afonso, carta desde Faro de 20 de julio de 1964. Coimbra: Archivo del Centro de Documentação 25 de Abril, Espólio Rui Pato, Correspondência Zeca-Albano de Rocha Pato, pasta XLVI, n. 14.

25 Daniel Lacerda, "O movimento estético que abalou Salazar”, Latitudes, 26 (2006), p. 37. 
zarista. ${ }^{26}$ Que Quintela pensara en José Afonso para poner música a estos poemas supone encomendarle el papel de traductor musical de Brecht en Portugal y, por tanto, que las canciones de Afonso presentaban ya, a ojos de los intelectuales de la oposición marxista al régimen, características que eran indicadas para fundir cultura popular, agitación política y resistencia cultural.

Aunque más cercanos al realismo de Lukács, la sintonía con Brecht era natural en un movimiento como el neorrealismo que utilizó diversos modelos narrativos siempre en la construcción de un sujeto popular emancipador. En sus tiempos de estudiante en Coimbra, José Afonso se familiarizó con la corriente, leyendo a los poetas del Novo Cancioneiro. Algo, no obstante, en la poética de estos no acababa de convencerle del todo y manifestaría posteriormente que "solo sentía el neorrealismo de forma indirecta". ${ }^{27}$ En realidad, desde sus mismos comienzos como compositor de canciones, actúa sobre su producción un abanico complejo de diversas fuerzas poéticas. En una primerísima fase, ya se pueden detectar en sus grabaciones desde una vaga influencia de la modernidad esteticista ligada a la revista Presença - especialmente a través de la poesía y canto de Edmundo Bettencourt - hasta derivaciones del surrealismo, de la chanson francesa y del neorrealismo. ${ }^{28}$ A partir de Dr. José Afonso em Baladas de Coimbra (1963), esto es, en el momento en que afina y concreta el instrumental lírico de denuncia, la decantación de su poética hacia una síntesis personal - en la que fagocita incluso elementos experimentales al servicio de la intervención política - facilita su atracción

${ }^{26}$ Carlos Castilho Pais, "Apontamentos sobre a maldita censura aos poemas de Brecht", en $<$ https://carloscastilhopais.files. wordpress.com/2010/01/apontamentos20brecht.pdf>; consultado el 19 de diciembre de 2019.

27 José António Salvador, Zeca Afonso. Livra-te do medo (Lisboa: Porto Editora, 2014), p. 73. José Afonso conocería personalmente a destacados representantes del movimiento como Carlos de Oliveira o Manuel da Fonseca.

28 Afonso admiraba a Bettencourt "Pela extrema simplicidade e pureza do seu canto"; citado en António Dos Santos e Silva, Zeca Afonso antes do mito (Coimbra: Minerva, 2000), p. 34. En 1960 graba "Mar Largo" con letra de Bettencourt. "Senhor poeta" (1962), con letra de Barahona de Fonseca, da cuenta de una temprana fascinación con los juegos verbales y las imágenes surrealistas. "No Lago do Breu” (1962), en otra dirección, presenta influencias confesas de George Brassens y su temática es neorrealista. hacia un autor como Brecht. ${ }^{29}$ En cierto sentido, este viraje es perfectamente lógico puesto que el conservadurismo formal neorrealista, unido a su concepto utilitarista del arte, no le van a ser especialmente útiles en su búsqueda de una ampliación más moderna de las posibilidades de construcción de las canciones.

Sin agotar, ni mucho menos, los niveles de análisis, podemos esbozar una síntesis del proyecto estético afonsino: la tarea de cantautor popular como nuevo juglar que expone los procesos sociales ante el común de las gentes. Afonso elabora un mensaje del cual desaparece casi completamente el yo individual y "burgués" para constituirse en una especie de mediador que vertebra, concreta y produce los significados dispersos en la conciencia colectiva de resistencia. La verdadera novedad está en los medios de que se vale para lograr su propósito: manipulación (casi una prestidigitación) de los recursos retóricos de la lírica tradicional; acopio de voces y materiales musicales ajenos entre sí - tradicionales, pop e incluso cultos-, pero vinculados por un origen común en culturas sojuzgadas, colonizadas o contraculturas libertarias (movimientos juveniles de los 60, resistencia latinoamericana a las dictaduras, colonias africanas, campesinado, proletariado urbano, entre otros); imaginería amplísima que bucea tanto en el inconsciente colectivo rural como urbano, formalmente surrealista ("Senhor arcanjo", "O avô cavernoso", "Paz, poeta e pombas") a veces, neorrealista otras ("Mulher da erva", "Em terras de Trás-os-montes"), brechtiana muchas ("Ronda dos paisanos", "Os vampiros", "Os eunucos", "A formiga no carreiro", "Coro dos caídos"), o de pura efusión lírica: tanto de raigambre culta ("Cantares do andarilho"), popular ("Fui à beira do mar") $\mathrm{y}$, en contadísimas ocasiones, intimista ("Que amor não me engaña”). ${ }^{30}$ En paralelo, Afonso recurre a prácticas

29 Pereira Martins, "Rekonstruktion der Poetik", p. 90, afirma que el contacto en Faro entre 1961 y 1962 con miembros de la generación intermedia entre el surrealismo y Poesia 61 (Luiza Neto Jorge, António Barahona da Fonseca y António Ramos Rosa) dio pie a una nueva dinámica en su trabajo poético.

${ }^{30}$ Aunque no es el tema central de este artículo, la vinculación, frecuentemente asumida, de José Afonso con el surrealismo literario en cuanto movimiento es problemática y debe ser examinada con más detenimiento. Si bien es indiscutible su cercanía a muchos de los procedimientos del surrealismo específicamente portugués (humor, escarnio, manipulación del lenguaje popular, imagen surrealista, revalorización lírica de lo cotidiano, etc.), no pasan de ser medios en una plasmación de la rela- 
narrativas dialécticas de acercamiento a las injusticias sociales a caballo entre la ironía, la identificación, la denuncia, la fragmentación en planos de la narración a la manera de un guión cinematográfico, el sarcasmo, la tensión heroica o la visión utópica. Por último, él encarna todo el proceso en una voz recorrida secuencialmente por la rabia, la violencia, el humor y la melancolía. Para la comprensión y ensamblaje de este mecano abierto a múltiples variables de la forma, parece que el modelo teórico de Brecht, combinando variados utensilios estéticos para fracturar el orden representativo burgués, se revela como el más adecuado. ${ }^{31}$

En relación a la apropiación directa de los presupuestos estéticos de Brecht, tenemos buena muestra en el uso de la idea de música gestual por parte de José Afonso. Cualquiera que haya observado la actitud de este durante las actuaciones en vivo, reconocerá dos elementos distintivos: una renuncia extrema al vedetismo, esto es, un intento de alejar de su propia imagen corporal la atención de la audiencia en favor del impacto atribuible al propio gesto musical, y una realización de este último como una

ción entre realidad y poesía muy distinta de la de aquel. El texto poético en colaboración con la música no es, para el cantautor, una vía en sí misma de conocimiento o de "iluminación", sino un filtro para sacar a la luz significados velados o reprimidos en lo real (o directamente censurados) y provocar una emoción o reflexión crítica sobre las contradicciones sociales. Esto es explícito en unas notas manuscritas sobre la letra de la canción "Venham Mais Cinco" donde alude a la necesidad de "alegorizar" o "entrar nos domínios do surrealismo" para sortear el servicio de censura de la prisión. Por otro lado, hay que destacar que José Afonso admite la influencia de las lecturas surrealistas y habla de la concepción de sus poemas como un estado muy próximo a los procedimientos de automatismo creativo del surrealismo. Véanse Salvador, Zeca Afonso. Livra-te do medo, pp. 56 y 212; Perfecto Cuadrado, "Situación histórica de la poesía surrealista portuguesa 1: el surrealismo portugués en el contexto de la literatura portuguesa contemporánea", Mayurqa: revista del Departament de Ciències Històriques $i$ Teoria de les Arts, 19/2 (1979-1980), pp. 93-26; y, del mismo autor, "Situación histórica de la poesía surrealista portuguesa 2: surrealismo, movimiento surrealista y poesía surrealista en Portugal", Caligrama. Revista insular de filología, 1/1 (1984), pp. 91-135.

${ }^{31}$ En una conversación con el autor en Évora (19/08/2019), Vitorino Salomé, músico, amigo y colaborador de José Afonso - en proyectos como Coro dos Tribunais, el álbum brechtiano por excelencia del cantautor - confirmó la importancia de Brecht como una de las influencias esenciales que marcaron su obra. toma de posición estético-política ante el conjunto social. De hasta que punto esto era un planteamiento consciente da testimonio la siguiente declaración:

Quando eu convidava as pessoas a darem os braços e a cantarem, é evidente que eu não tinha nehuma batuta... mas todos os recursos que pudesse utilizar no mínimo espaço de tempo para criar espírito de insubordinação, eu usava-os. O Brecht fala muito nessa linguagem gestual e na importância que reveste. ${ }^{32}$

Pero no debemos olvidar la otra cara de la "gestualidad" musical: el entresacar de prácticas musicales tradicionales un tipo de métrica y organización estrófica, de ritmo musical sostenido y flexible y de fórmulas melódicas abiertas que se adapten a una nueva capacidad que podríamos llamar lírico-narrativa. Para justificar esta opción, José Afonso manifiesta:

Toda a perspectiva progressista é compatível com aspectos conservadores da cultura que se pretenda conservar. O Brecht, com certeza, utilizou tradições da Alemanha e tradições do teatro chinês. Todos os trabalhadores da arte utilizam as tradições dos povos. Pelo contrário, penso que é retrógado cortar abruptamente com tudo isto e entender que o que é necessário é fazer uma sociedade à imagem e semelhança de um outro tipo de sociedade. ${ }^{33}$

Podríamos traer aquí a colación una categoría desarrollada por Ernst Bloch: die Erbe (la herencia). Con ella, el filósofo llama al uso del pasado cultural pre-capitalista (popular, campesino, primitivo) para renovar las perspectivas utópicas frente al agotamiento de la visión teleológica marxista. En los nuevos artefactos musicales de José Afonso, los ritmos latinoamericanos o africanos, las polifonías rurales alentejanas, los metros de la lírica tradicional portuguesa, plasmarían un intento de despojar este vocabulario estético, en la línea apuntada por Fredric Jameson, de los mitos sentimentales y populísticos del pasado cultural remoto. ${ }^{34}$ José Afonso almacena, por decirlo así, un stock muy rico de este tipo de recursos y los pone

32 Salvador, Zeca Afonso. Livra-te do medo, p. 250.

${ }^{33}$ Belino Costa, "Conservar a cultura não é ser conservador", entrevista a José Afonso en $\mathrm{Se} 7 e$ (25 de noviembre de 1981).

${ }^{34}$ Fredric Jameson, "Afterword", en Aesthetics and Politics, ed. Ronald Taylor, pp. 196-213, esp. 210, recurre a las ideas de Bloch en su intento de buscar una salida al problema de la integración por el capitalismo de la crítica mediante el arte. 
al servicio de operaciones narrativas cuya finalidad es construir un relato contrahegemónico de la realidad socio-política portuguesa a partir de episodios con un cierto contenido "épico"; particularmente, señalaríamos el álbum Com as minhas tamanquinhas (1976) como verdadero muestrario de estas formas "gestuales". ${ }^{35}$ Viriato Teles también subraya esta similitud con las creaciones de Brecht, situando al álbum en una línea de intervención radicalmente alejada del realismo socialista. ${ }^{36}$

Volvamos al recorrido histórico. La influencia de Brecht como mentor intelectual y artístico de los movimientos opositores a la dictadura portuguesa es de una enorme significación. Cabe a la revista Vértice, ya citada, y, en concreto, al crítico y ensayista Luiz Francisco Rebello la iniciativa de dar comienzo a la divulgación y discusión de su obra y pensamiento desde $1949 .{ }^{37} \mathrm{La}$ censura, consciente del potencial tanto de movilización como de revulsivo estético que tenía Brecht, prohibió las representaciones de sus dramas y reclamó la supresión de cualquier referencia a él en revistas o periódicos. Más benévolo, aparentemente, era el aparato represor salazarista con la circulación impresa de las traducciones de las piezas teatrales y los poemas. Esta situación favorecía un constante juego del ratón y el gato entre los grupos predominantemente aficionados y universitarios que buscaban sacar a la luz sus dramas y el Secretariado Nacional de Información para evitarlo o expurgarlo del contenido "peligroso". 38

En Mozambique, adonde Afonso se había trasladado en 1964 , la situación no era muy distinta, aunque la

35 Por citar tan solo un ejemplo: la narración de la detención y tortura del líder de las revueltas campesinas brasileñas Alípio de Freitas por la CIA se desarrolla envuelta por la atmósfera animada y optimista que provee un ritmo, tono melódico elegíaco y arreglos emparentados con usos similares del folclore andino por la Nueva Canción Chilena. El resultado emocional es el refuerzo de un impulso de resistencia y esperanza que contrasta, "distanciándose", con el contenido dramático factual de los hechos.

36 Viriato Teles, As voltas de um andarilho. Fragmentos da vida e obra de José Afonso (Lisboa: Assírio \& Alvim, 2009), pp. 158-59.

${ }^{37}$ Márcia Regina Rodrigues, Traços épico-brechtianos na dramaturgia portuguesa: O render dos heróis, de Cardoso Pires, e Felizmente há luar!, de Sttau Monteiro (São Paulo: Cultura Acadêmica, 2010), p. 27.

38 Rodrigues, Traços épico-brechtianos, pp. 36-39. lejanía de la metrópolis favorecía soluciones ingeniosas. ${ }^{39}$ El cine club de la ciudad de Beira, fundado en 1956, se había constituido en uno de los principales centros de renovación cultural y agitación política de la ciudad al aglutinar a un núcleo de entusiastas reunidos con grandes dificultades en torno al cine comprometido y de vanguardia europeo. En 1966 la representación de A excepção e a regra de Bertolt Brecht supuso un hito en la trayectoria del cine club. La puesta en escena estaba a cargo de José Cardoso, fundador del mismo, cineasta y escenógrafo; José Afonso participó poniendo música a las canciones que el dramaturgo incluye en la obra y adaptando sus textos. Varios factores cargan de significación este momento. La pieza resultaba ser la primera obra de Brecht en ser traducida al portugués en 1957 por Luiz Rebello como parte de su proyecto de introducción del universo brechtiano en la cultura lusa. Se da la circunstancia, además, de que el montaje en aquel remoto paraje mozambiqueño suponía la primera vez que un grupo de teatro portugués, aunque fuera aficionado, llevaba a escena una obra íntegra de Brecht. ${ }^{40}$

El enfrentamiento directo con el teatro de Brecht actúa a la manera de una sacudida existencial en el curso vital y artístico de Afonso. El cantautor se encontraba en medio de una profunda crisis determinada por el final de su estancia en Mozambique y la inminencia de su regreso al continente europeo. En su escueta autobiografía, firmada en Beira en abril de 1967, algo más de tres meses antes de su partida, contempla el encuentro como un gozne que cierra una puerta (la etapa de "las baladas") y abre la oportunidad a realizaciones de otro fuste, aunque encara el futuro con fatalismo ante lo incierto del panorama que tenía por delante.

Mais umas baladas (as últimas) e uma tranferência para a Beira. Novo lapso e uma última oportunidade que me veio através do TAB (Teatro dos amadores da Beira). Car-

${ }^{39}$ Léase el divertido relato que hace João Afonso dos Santos, José Afonso - Um Olhar Fraterno (Lisboa: Caminho, 2002), pp. 178-80, de las esperpénticas peripecias necesarias para lograr la autorización del censor local para la representación; José Afonso se negó a cantar en una sesión de fados si no se autorizaba la pieza.

40 Antonio Iglesias Mira, "O goberno portugués contra Castelao: a aventura galega do CITAC", Abriu: estudos de textualidade do Brasil, Galicia e Portugal, 4 (2015), pp. 61-75, especialmente p. 71. 
doso dos Santos empenhava-se num prazo mínimo de tempo em preparar a encenação de "A excepção e a regra" de Brecht. Faltava musicar e adaptar as canções que figuravam na tradução de Francisco Rebelo. Assim fiz. Depois disto a mudez ou a decadência. Não sei bem. ${ }^{41}$

Si bien esta percepción de Brecht como revulsivo debe ser remitida a este momento particular de su vida, la reflexión que antecede a esta confesión no deja dudas sobre su necesidad de encarar realizaciones creativas de más calado con respecto a la etapa que dejaba atrás. Creador de una nueva tipología en la música popular portuguesa, denominada como baladas, se refiere a ellas en estos términos: "Mais do que simples forma musical vagamente lúdica ou combativa definiam uma atmosfera pré-existente nas coisas presentes e passadas. Nada mais do que um folclore de segunda ordem pronto a servir". ${ }^{42}$

Por contra, a partir de la composición de las canciones y adaptación de la traducción de Rebello, José Afonso hace gala de un interés especial en que los textos lleguen cuanto antes a formar parte de la segunda edición de Cantares, el primer libro impreso con las letras de sus canciones, editado por Rui Mendes en Tomar (Portugal) en 1966. A 3 de enero de 1967, José Afonso envía los textos por carta a Rocha Pato: "Mando-lhe as últimas letras duma peça do Brecht 'A Excepção e a Regra' adaptada e musicada. Poderá confrontar a tradução de Francisco Rebelo"; y le ruega que se ponga en contacto con Pedro Borges, un amigo suyo que ha llevado una grabación de los temas a Coimbra "Tente passar para um gravador essas mesmas canções. Pode tirar uma copia e dá-la ao Rui Mendes" ${ }^{43}$ El 6 de marzo del mismo mes escribe: "Mostre-lhe as minhas versões do Brecht. Nutro um especial interesse em que figurem na segunda edição juntamente com a última versão de "Avenida de Angola". ${ }^{44}$

${ }^{41}$ José Afonso, Cantares (Lisboa: Associação de Estudantes do IST, 1968), p. 13.

${ }^{42}$ Afonso, Cantares, p. 12

43 José Afonso, carta desde Beira de 3 de enero de 1967. Archivo del Centro de Documentação 25 de Abril en Coimbra. Espólio Rui Pato. Correspondência Zeca-Albano de Rocha Pato, pasta XLVI, 29.

${ }^{44}$ José Afonso, carta desde Beira de 25 de marzo de 1967. Archivo del Centro de Documentação 25 de Abril en Coimbra. Espólio Rui Pato. Correspondência Zeca-Albano de Rocha Pato, pasta XLVI, 30. Los textos no vieron finalmente la luz hasta la tercera edición del libro, realizada clandestinamente por la Asociación de estudiantes del Instituto Superior Técnico de Lisboa.
Una vez de vuelta en Portugal, y forzado por su expulsión de la enseñanza, José Afonso inicia una etapa diferente en su producción, marcada drásticamente por la profesionalización musical. Esta fase (1968-1970) gira predominantemente en torno a la reivindicación antropológica de la música tradicional campesina de Portugal. La impronta de Brecht no deja de hacerse presente en la puesta en práctica literal de su llamada a la apropiación del lenguaje popular, su elaboración narrativa y devolución en la forma de composiciones intencionalmente inscritas en la lucha de las capas oprimidas por su emancipación

E os cantores até nem são na sua grande maioria, verdadeiros cantores populares, já que o seu canto não surgiu do interior da própria luta, embora se refiram a ela. O nosso amigo Brecht salvaguardava cuidadosamente essa distância. $^{45}$

Lateralmente, se debe anotar su localización en el entorno del CITAC (Círculo de Iniciação Teatral da Academia de Coimbra), grupo de teatro experimental de fuerte implicación con Brecht dirigido en ese momento por el catalán Ricard Salvat. José Niza, autor de la música de A excepção e a regra, representada de forma semi-pública en 1969, pensó en José Afonso para dar forma a una selección en disco de las canciones del espectáculo, lo que fue rechazado por Salvat en base a que Afonso aportaría un "tono de profesionalidad" que no convenía al resultado. Con todo, este proyecto no llegaría a ver la luz. ${ }^{46}$

De forma escalonada, las canciones que compuso Afonso en Mozambique van materializándose a lo largo de los años siguientes en sucesivos fonogramas, antes y después de la volcánica fecha del 25 de abril de 1974. Estas grabaciones constituirán el asunto del siguiente apartado.

Un oficio de la Dirección General de los Servicios de Censura de 21 de mayo de 1968 prohibiendo la circulación de esta edición lleva a suponer que esta fuera impresa en ese año. Véase https:// tributozecafonso.blogs.sapo.pt/livro-cantares-de-jose-afonso-28215; consultado el 18 de enero de 2020.

45 Declaraciones de José Afonso a Página Um, 31-03-1977; citado por José Amaro, O discurso do poder do estado (Coimbra: Via Editora, 1978), p. 94.

46 Antonio Iglesias Mira, "Castelao e a sua época na Coimbra de 1969", tesis de máster, Faro: Universidade do Algarve, 2011, anexos 7 y 8 . 


\section{1. "É para Urga" y las canciones de José Afonso para $A$ excepção e a regra}

De acuerdo a los textos que José Afonso envió desde Beira (Mozambique) para su publicación en Cantares, el artista compuso cuatro canciones sobre adaptaciones de la traducción de Francisco Rebello para A excepção e a regra de Brecht: "Canta o comerciante (Eu marchava de dia e de noite)", "Canta o juiz (Que o teu inimigo queira)"; "Canta o coolie (A caminho do Urga)" y "Canta o coolie (Alí está o rio)" ${ }^{47}$ No obstante, su hermano, João Afonso, y Álvaro Simões, actor en la pieza, mencionan también la composición de "Coro dos Tribunais" 48 , lo que se comprueba por su grabación posterior en el álbum del mismo título; en sentido inverso, "Canta o juiz" no llegaría nunca a ser grabada. La tarea concreta que tenemos ante nosotros tiene como objeto central la identificación de los componentes de parentesco estético brechtiano en la serie de grabaciones de aquellas canciones realizadas en formato LP para la casa discográfica Orfeu de Arnaldo Trindade: "É para Urga", cara B, pista 4 en Eu vou ser como a toupeira (Orfeu, STAT 017, 1972); "Coro dos tribunais", cara A, pista 1 (vocal) y cara B, pista 6 (instrumental) en Coro dos tribunais (Orfeu STAT 026, 1974); "Eu marchava de dia e de noite", cara B, pista 1, en Coro dos tribunais y "Ali está o rio", cara A, pista 4 en Enquanto há força (Orfeu, STAT 054, 1978).

La excepción y la regla (Die Ausnahme und die Regel, 1929) pertenece al ciclo dramático al que Brecht denominó Lehrstücke (piezas didácticas), concebidas como un instrumento práctico al servicio de la divulgación del socialismo. En ella colisionan dos personajes representativos de las relaciones en la sociedad de clases: un comerciante - que debe llegar a través del desierto a la ciudad de Urga antes que sus competidores para cerrar un tratoy su porteador (coolie), hombre sencillo y bondadoso, cruelmente maltratado y despreciado por aquel. La acción llega a su culmen cuando el comerciante mata al porteador, confundiendo un gesto de generosidad (el ofrecimiento de agua) con un intento de agresión. Posteriormente, en los tribunales, la justicia resuelve a favor del comerciante, argumentando que tenía el derecho de defenderse ante lo que él creía una amenaza.

47 Afonso, Cantares, pp. 88, 90, 91 y 92.

48 Afonso dos Santos, José Afonso. Um Olhar Fraterno, p. 128 .
Las canciones insertas en la obra, cumplen el papel, asignado por Brecht, de interrumpir la acción dramática, concretando la posición moral e ideológica de estas figuras, que es lanzada directamente sobre el espectador, apartándolo sin contemplaciones de la continuidad de la historia. Son las responsables primeras de desmontar la tramoya de la representación, inducir a la reflexión crítica y provocar sentimientos de desagrado y rebelión frente a lo que allí se cuenta. ${ }^{49}$ Inducen al público a una inevitable toma de posición. Con esto en mente, João Afonso apuntaba que las canciones de su hermano estaban destinadas "a assegurar o necessário distanciamento brechtiano da representação dramática" ${ }^{50} \mathrm{El}$ trabajo textual y musical de José Afonso con la traducción de Rebello acrecienta aún más la dimensión de signo de puntuación, ruptura o condensación de la denuncia ideológica por parte de las canciones con respecto a la acción teatral. Llevadas a un terreno distinto, aquel de la recepción de los discos, el tratamiento musical en las grabaciones terminará de dotarlas de todo su potencial de desasosiego cultural en el Portugal de los últimos años de la dictadura y primeros momentos de la Revolución.

Por razones de espacio, nos ceñiremos a la primera canción del porteador (coolie) contraponiéndola después a la del comerciante. Las dos son ejemplos de cómo una selección individualizada de recursos musicales aparentemente simples crea un artefacto estético complejo que ensancha el horizonte hermenéutico sin por ello difuminar el perfil simbólico de los personajes. La presentación de la temática brechtiana se produce en el álbum Eu vou ser como a toupeira de 1972. Existe una coherencia temporal con los desarrollos anteriores puesto que el director musical del trabajo es José Niza, cuya familiaridad con La excepción y la regla hemos comentado ya. Después del aldabonazo que sacudió la canción portuguesa con Cantigas de maio y sus arreglos vanguardistas, en este disco José Afonso y sus colaboradores vuelven a un planteamiento más sobrio caracterizado en las páginas de Mundo da canção por dos elementos definidores: la instrumentación resuelta colectivamente al servicio de la primacía de una voz calificada como "significante" y una

\footnotetext{
49 John Willet, El teatro de Bertolt Brecht. Un estudio en ocho aspectos (Buenos Aires: Fabril, 1964), p. 254.

50 João Afonso dos Santos, "La no Xipangara", AJA, revista da Associação José Afonso, 7 (1993), p. 30.
} 
poesía accesible en formas y léxico. ${ }^{51}$ Es en este marco donde inscribir el tratamiento dado por José Afonso a las partes cantadas por el coolie en la canción "É para Urga" ${ }^{52} \mathrm{El}$ texto original expone la visión interiorizada del porteador en la que Urga es un lugar concreto donde satisfacer las necesidades materiales y afectivas:

Em Ourga recebo o salário e tiro a barriga de misérias. [...]

Minha mulher está em Ourga,

meu filho também lá está,

Para alcanzar ese lugar, la vida del siervo debe afrontar un duro periplo de fatigas y penalidades:

Muito custa chegar a Ourga:

grande é o sofrimento no caminho até Ourga: ${ }^{53}$

Se seleccionan los elementos que configuran a Urga como una meta fruto de la dirección inexorable de la Historia:

É para Urga

Que a gente vai

Em Urga caminho

Caminho pr'a lá

Y se eleva la voluntad de victoria a aspiración colectiva mediante el uso de los coros y su colocación en el primer plano del estribillo:

Eu hei-de vencer

Eu hei-de vencer

Entre mim e Urga

$\mathrm{O}$ deserto que houver. ${ }^{54}$

Dejando de lado aquellos aspectos relacionados con la crueldad de la opresión, Urga se convierte en una

51 Tito Livio, "Três albuns importantes. Uma canção significante", Mundo da Canção, 34 (1973), p. 7.

52 La canción "É para Urga” cantada por José Afonso puede escucharse en el siguiente enlace de YouTube: $<$ https://www. youtube.com/watch? $\mathrm{v}=\mathrm{M} 6 \mathrm{w} 4 \mathrm{atdTCGE}>$.

${ }^{53}$ Luiz Francisco Rebello, Teatro moderno: caminhos e figuras (Lisboa: Prelo, 1964), p. 540. Reproducimos literalmente la distribución y puntuación de los versos en esa edición.

54 José Afonso, letra de "Eu para Urga", en Eu vou ser como a toupeira (Orfeu, STAT 017, 1972), según aparece en la carpeta del vinilo original. representación simbólica de utopía, el lugar donde se realiza la transformación definitiva del proceso de lucha por la liberación en un espacio justo y seguro, con el añadido de que se superponen sentidos subliminales al contexto de la acción dramática de partida. A lo que era entonces exclusivamente un manifiesto anti-capitalista se le suma ahora en el ámbito político de la escucha una convocatoria optimista y metafórica a la unión para el derrocamiento del régimen. La crítica del momento entendió esto perfectamente: "Um disco que resume e contém as constantes de um tempo doloroso no espaço que vivemos". 55

La inteligencia con que está resuelta la retórica musical y expresiva de "É para Urga" nos permite aventurar que nos encontramos con una demostración de cómo la estrategia del "collage" pop, tan sabiamente utilizado por José Mário Branco en el disco anterior, se puede reducir a la mínima expresión, revelándose además en cuanto procedimiento de crítica cultural como legítima heredera de aquella "yuxtaposición de fragmentos y ruinas" característica de la música brechtiana.

La base rítmica armónica e instrumental del tema es de una sencillez sin trampa ni cartón. Sobre un ritmo saltarín en 2/4 que subraya casi en pizzicato las dos primeras corcheas de cada parte del compás, el movimiento armónico gira en una oscilación continua, pasando ágilmente de la tónica a la subdominante dentro de un compás para descansar en la tónica en el siguiente. El tempo está a mitad de camino entre andante y allegretto.

55 Livio, "Três albuns importantes", p. 7. De hecho, los discos entre 1972 y 1978 pueden ser considerados como respuestas (réplicas en palabras de José Afonso) a la situación socio-política vigente. En 1972 el impulso de contestación ciudadano y militar a la denominada "Primavera Marcelista" (en alusión a la supuesta apertura publicitada por Marcelo Caetano) era ya tan ostensible que el tono del disco es de llamada encubierta a la insurrección. Coro dos tribunais, grabado apenas unos meses después del derrocamiento del régimen en abril por la Revolución de los Claveles, es el primer disco donde José Afonso puede gritar abiertamente su indignación contra la situación de opresión y desigualdad legada por el régimen. Posteriormente, el artista adoptaría en Com as minhas tamanquinhas (1976) una posición radical y nítida ante la contraofensiva contra el P.R.E.C. (Processo Revolucionário em Curso) desatada en noviembre de 1975 desde el ala conservadora del F.M.A. (Movimento das Forças Armadas) junto con la Socialdemocracia y la derecha. 
La guitarra introduce la canción exponiendo un intervalo de segunda menor que cobrará después una importancia fundamental como transmisor en los coros del pequeño movimiento de avance repetido que conduce hacia el triunfo; debajo, la insistencia sobre la tónica en la segunda y cuarta corchea del compás plasma el aire trotón de la marcha del porteador. Al tomar impulso para repetir el esquema, el xilófono interrumpe en síncopa este descanso con una figuración puntillista y risueña que resuena como la llamada de una campanilla en la distancia. En conjunto, la introducción instrumental define una atmósfera de excursión a buen paso con el xilófono como estímulo.

En su entrada, marcando el objetivo tanto simbólico como ideológico de la travesía, José Afonso usa la voz, situada en un registro muy cómodo, con una emisión cálida, natural y relajada, casi de confidencia. El reverb amplifica la resonancia de la emisión desnuda con el único acompañamiento del bajo. El ritmo armónico implícito es básicamente el mismo de la introducción, resaltando el significativo detalle de que la secuencia subdominante-tónica se produce ahora sobre la palabra Urga. La célula melódica, reminiscente de muchas canciones infantiles, conduce la tercera vez a una escala ascendente que señala el "Caminho pr'a la" justamente sobre la cadencia. Esta se resuelve con la convicción de que "Os bandidos não me hão-de apanhar". Seguidamente, como contestación triunfal a estas revelaciones evocadoras del mundo confiado de la infancia, un coro masculino tímbricamente redondeado y asertivo entona el "Eu hei-de vencer" por duplicado; véase Ejemplo 1. La sonoridad de los acordes mayores subraya ahora el paso del intervalo de segunda con un efecto clamoroso. Se trata del mismo pivote rítmico-melódico colectivo sobre el que los escolares recitaban la tabla de multiplicar elevado a la categoría de himno ingenuo en el que la repetición posee el mismo carácter nemotécnico para la memorización del resultado. En la segunda exposición de esta frase, la letra presenta gozosa el sueño ya cumplido. "Em Urga recebo / A maquia e então / Vou tirar proveito / do meu ganha-pão". Es de notar el cambio de espectro comunicativo operado por la sustitución del término neutro de Rebello salário por ganha-pão y maquia, palabras de sabor y uso mucho más popular, en un nuevo ejemplo de acuerdo con la estrategia brechtiana de integración del lenguaje común en el discurso crítico. Las condiciones materiales del coolie quedan por tanto vinculadas a las expectativas de las clases desfavorecidas portuguesas.

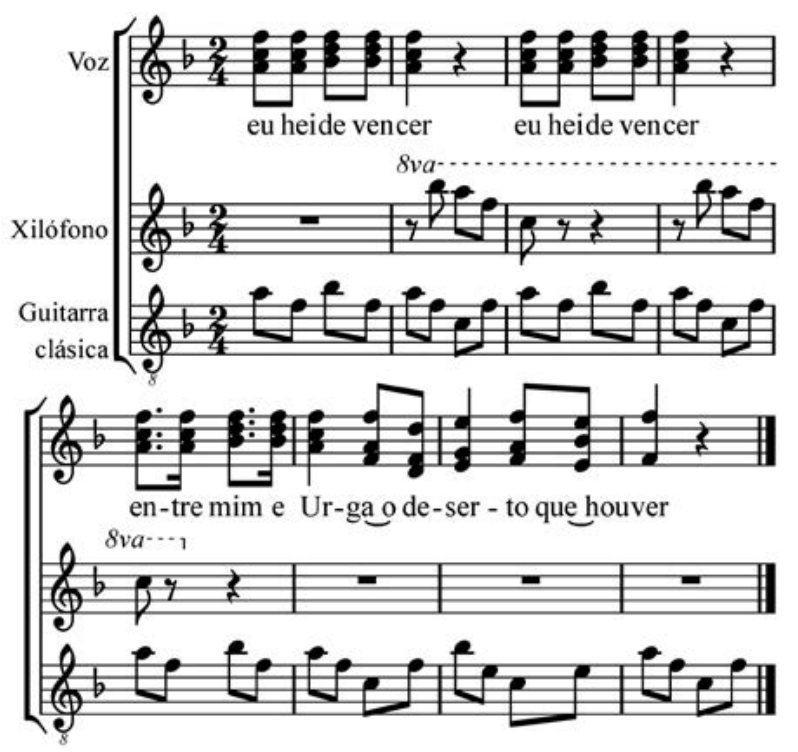

Ejemplo 1. José Afonso, "É para Urga”, coro triunfal.

En la transición hacia la repetición íntegra literal de toda la estrofa se produce un divertido golpe de efecto, en tono abiertamente irónico, mediante la incrustación de una frase ajena a todo el material anterior, dibujada con fórmulas de la escala pentatónica tradicional china; véase Ejemplo 2.

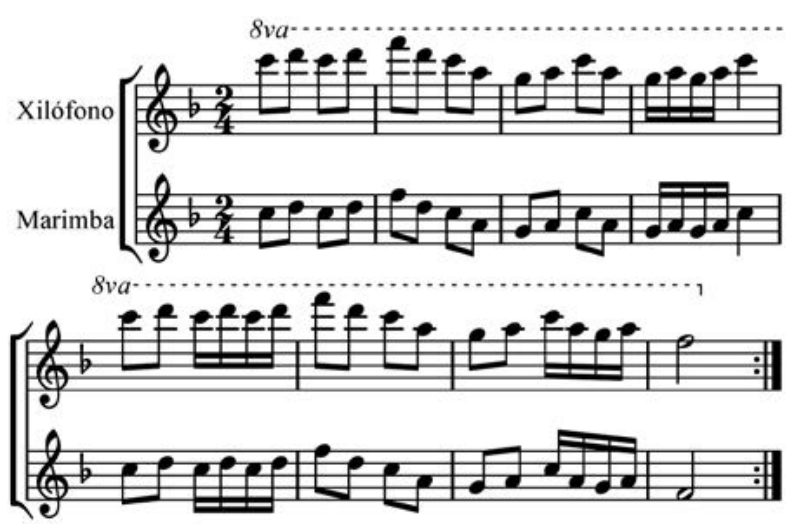

Ejemplo 2. José Afonso, "É para Urga", chinoisserie.

Su ejecución en el xilófono, instrumento escolar por excelencia, dota a este interludio de un aire juguetón de cajita de música. Aquí reside el punctum que produce el extranamiento con respecto a las "evidencias" sugeridas por el continuum texto-música-voz-performance. Un uso tan ab- 
solutamente deliberado del cliché reconfigura por completo la percepción y la actitud del oyente de la canción. El relato sostenido hasta ahora como hemos visto por claves retóricas que permiten una identificación con el mensaje de lucha y victoria intensifica su carácter simultáneo de ejercicio lúdico con la doble consecuencia de la contextualización de la narración como un producto convencional e histórico y la restitución del disfrute placentero a todo el artefacto; así se muestran las dos facetas que Brecht exigía a cualquier obra de arte que pretendiera ser ideológica y estéticamente eficaz.

Georges Didi-Huberman ha puesto el acento en esta dimensión de juego constructivo inherente a los montajes de imágenes y poemas de Brecht, en los que la imaginación asume la tarea de re-posicionamiento de elementos dotados cada uno de su propia cronología. Las relaciones simbólicas que permiten una reflexión crítica sobre lo real se establecen mediante una articulación de las diferencias. ${ }^{56}$ En este caso, además, se trata directamente de juego escenificado musicalmente, con su doble sentido de placer e instrucción. Paralelamente, este recurso al cliché, añadido a la puesta en escena "infantil" del tema, colabora también en la producción de otro efecto crucial para las tesis brechtianas, en concreto, romper la identificación entre cantante y canción. ${ }^{57} \mathrm{Al}$ no dialogar ya con la representación teatral propiamente dicha, sino presentarse como construcción sustantiva, el exotismo paródico de la cita dota a esta de un carácter de fábula con moraleja, situando al narrador como mero intermediario del cuento. Para dejar esto claro, la chinoiserie cierra la pieza, enmarcándola y completándola. ${ }^{58}$

\footnotetext{
${ }^{56}$ Georges Didi-Huberman, Cuando las imágenes toman posición (Madrid: Antonio Machado libros, 2008), p. 230. De hecho, la tarea musical es siempre un trabajo de com-posición, de recombinatoria de elementos tomados de la memoria en un eje temporal y espacial que teje una red nueva de temporalidades. La cuestión crucial, por supuesto, concierne a qué elementos y tomados de qué posición cultural se utilizan.

${ }^{57}$ Lo que José Mário Branco denominaba "argumentar com o cliché", esto es, "dar o toque que permita libertar o ouvinte do cliché e puxá-lo para um nível qualitativo superior. É educar o gosto", en Gonçalo Frota, "Deixou de haver ética e sangue na criação artística. Entrevista a José Mário Branco", Público [Portugal] (28 de noviembre de 2017). En https:/www.publico. pt/2017/11/28/culturaipsilon/entrevista/jose-mario-brancodeixou-de-haver-etica-e-sangue-na-criacao-artistica-1794087; consultado el 19 de noviembre de 2019.

${ }^{58}$ En diversos lugares, Brecht se interesa por la música tradicional china debido a su carácter gestual; véase Brecht, Music \& Culture, ed. Berendse y Clemens, pp. 41 y 56. Esto responde
}

En comparación con "É para Urga", los arreglos y la interpretación de "Eu marchava de dia e de noite" incluida en Coro dos tribunais (1974) elaboran un escenario completamente distinto.$^{59}$ La traducción musical de la proclama del comerciante no sufre aquí alteración alguna en lo que respecta al contenido literario. Es palmaria la desnudez y la dureza con la que Brecht acota en las sucesivas intervenciones musicales del personaje el envoltorio ideológico que encubre la realidad de la explotación. Reproduciendo la antipatía profunda que una exposición tan cruda y manifiesta de la tesis de que el fuerte debe destruir al débil para obtener el beneficio económico produce en el espectador, José Afonso no añade aquí nada de su cosecha; se limita a reelaborar poéticamente las ideas para cenirlas a la estructura de una forma estrófica estricta.

Un giro brusco en la sección central de la melodía en cada estrofa se traba en una rítmica irregular y sincopada respondiendo al enfrentamiento dramático y dialéctico entre los términos de una contradicción de clase social: "Ao rico uma ajuda e ao pobre uma surra" ${ }^{60}$ Añádase a esto un ostinato obsesivo del bajo de la guitarra al comienzo marcando las cuatro apresuradas corcheas del compás y un matiz de predicador, de vibrato enfático y algo agresivo en la voz de José Afonso y tenemos la expresividad adecuada para la ansiosa prepotencia del personaje. Lo desestabilizador viene aquí de la mano de Fausto Bordalo, arreglista y director musical del álbum. Un incómodo gesto armónico establece desde la introducción de la guitarra una suerte de réplica a la neurosis del vencedor. Siempre que hay una afirmación en la tónica, esta se rompe por una sonoridad sumamente disonante tomada del jazz: un acorde de sexta con novena aumentada C(add69\#) se despliega usando las digitaciones del finger-picking del folk norteamericano en arpegios de dos acordes distintos, sin y con la quinta, dejando flotar una escala pentatónica reminiscente del blues: do, re\#, mi, sol, la, lo que provoca una especie de cojera emocional en esta frenética carrera hacia el éxito; véase Ejemplo 3.

a su interés por "conservar una forma vieja para elaborar contenidos nuevos" que Didi-Huberman, Cuando las imágenes, pp. 96 y127, contempla como un movimiento de transgresión.

${ }^{59}$ Puede escucharse "Eu marchava de dia e de noite" cantada por José Afonso en el siguiente enlace a YouTube: https:// www.youtube.com/watch?v=JOFmr_CN5PQ.

${ }^{60}$ Letra de "Eu marchava de dia e de noite", tal y como aparece en la carpeta del vinilo Coro dos tribunais (Orfeu, STAT 026, 1974). 

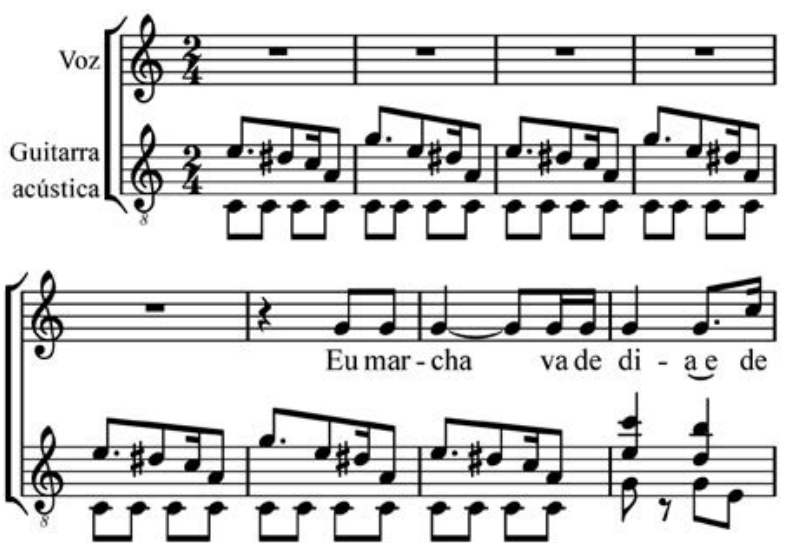

Ejemplo 3. José Afonso, inicio de "Eu marchava de dia e de noite".

No hay que descartar una voluntad por parte del tándem Afonso-Fausto de desplazar la asociación de este tipo de técnica y armonía en la guitarra acústica de cuerdas metálicas con el universo narrativo del blues a la inevitabilidad del orden social predicado en el texto, o incluso de una proyección irónica del Gran Hermano estadounidense sobre la figura del comerciante. Pero, por otra parte, el resto del acompañamiento emplea patrones recurrentes en el folk para acompañar relatos estróficos que implican un itinerario, travistiendo el horizonte polvoriento del Western en desierto mogol. El montaje (reflexividad) y la ambivalencia de los signos responden a criterios de lo que Lawrence Kramer llama el tropo moderno de extrañamiento. ${ }^{61}$ En el ejemplo que examinaremos a continuación dichas características se plantean en un paisaje expresivo mucho más complejo.

\section{2. "Vejam bem" (Beträchte genau $)^{62}$}

Prestemos atención a esta música. Ella misma lo reclama: "Vejam bem!”; ¡abran los ojos! ¡miren más allá de lo evidente! Un aldabonazo seco y escueto en forma de interjección musical. Dos corcheas en anacrusa seguidas de una negra con puntillo, en 6/8, marcan una quinta descendente a la tónica componiendo un musema de extraordinario poder imperativo; véase Ejemplo 4.

${ }_{61}$ Kramer, Musical Meaning, p. 220.

62 La canción "Vejam bem" cantada por José Afonso puede escucharse en el siguiente enlace a YouTube: https://www.youtube.com $/$ watch? $\mathrm{v}=\mathrm{mpOCF} 0 \mathrm{wiA} 5 \mathrm{~g}$.
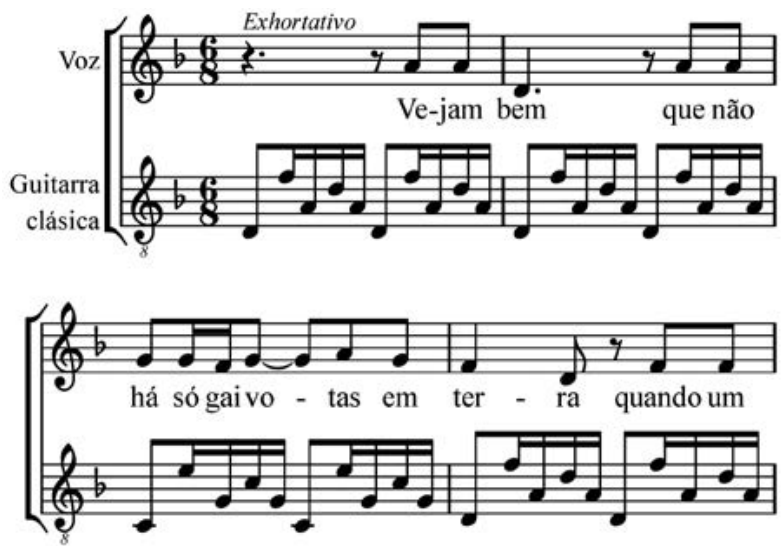

Ejemplo 4. "Vejam bem", entrada de la voz.

¿Y qué historia es esta a la que con tanta urgencia se nos insta a atender? José Afonso lo explica en las notas a los textos de Cantares:

Música do filme "O anúncio" [...] Um homem procura emprego num escritório, dirigese ao gerente de uma firma conceituada, a capatazes e mestres-de-obra. Em vão! Privado de fundos, vê-se obrigado a dormir ao relento e a roubar para comer. $\mathrm{Na}$ retrete de um restaurante, único lugar onde não é visto, devora apressadamente dois ovos que metera ao bolso, aproveitando-se da algazarra geral. É à luz deste contexto dramático que poderão entender-se a linha melódica e o texto rimado apensos às sequências julgadas mais expressivas. ${ }^{63}$

El cortometraje $O$ Anúncio (1966) presenta en un relato condensado (16 minutos), en sombrío blanco y negro sin diálogos, una visión transparente de los orígenes sociales de la indigencia. ${ }^{64}$ No obstante la deuda admitida por el director del corto - el mismo José Cardoso que dirigía La excepción y la regla - con el neorrealismo italiano de Vittorio de Sica, la sucesión de escenas pasa ante nuestros ojos con un aire extraño, casi onírico ${ }^{65}$ Es algo próximo a la melancolía humillada del payaso o incluso a una pesadilla, como en los planos que ponen en paralelo el jolgorio de los danzantes con la persecución de un huevo duro por parte del

${ }^{63}$ Afonso, Cantares, p. 45.

${ }^{64} \mathrm{El}$ cortometraje $O$ Anúncio es accesible en el siguiente enlace: https://netkanema.co.mz/programs/anuncio.

65 Teresa Sá Nogueira, "Cinema moçambicano", Tempo [Mozambique] (17/08/86), p. 43. 
protagonista entre los pies de aquellos y que finaliza con su aplastamiento casual.

Como expone Marilú João en el texto que acompaña al DVD, la responsabilidad de este tono "chaplinesco" de $O$ Anúncio hay que atribuirla a la combinación del blanco y negro, de la mudez (que otorga a la canción todo el peso oral) y de una interpretación muy sobria y neutral en las antípodas de la hiperexpresión melodramática que sería esencial para el desbordamiento de los sentimientos compasivos. El parentesco con Chaplin se concreta "num mesmo quadro temático - uma acentuação humorística, sarcástica e reveladora da condição humana nas sociedades modernas" ${ }^{66}$ En realidad, de lo que estamos hablando aquí es de esa expresividad social de las emociones propia del cine mudo y que es central a la noción de gestus. ${ }^{67}$ A esta exposición de singularidades en conflicto más que de individualidades, como diría Didi-Huberman, se suma la canción de José Afonso. El cantautor entra en la sala mientras la película está en la fase de montaje y pide añadir, superponer a los fragmentos que reconstruirán la historia, otro relato que, al no oírse otra voz que la suya sobre las imágenes, vendrá a constituir una traducción libre de un idioma al otro, hasta tal punto que el crítico de Vértice decía, tras la presentación, que el film discurría:

Parafraseando, imageticamente e num tom que tem qualquer coisa de chaplinesco, uma canção de José Afonso com a qual abre (após uma portada com sons naturais) e finaliza. ${ }^{68}$

Los dos lenguajes en un mismo plano se interpelan mutuamente. La construcción del significado del objeto fílmico deviene una función del montaje - entendido este en sentido brechtiano - porque la canción se presenta en su integridad, al modo de las interpolaciones musicales en las obras de Brecht y, como aquellas, apunta tanto con su dedo al espectador como altera la narración instaurando el tiempo de la polisemia. El continuum música-texto-voz no solo resume o selecciona aspectos de la historia y los pone a dialogar con el fluir concreto de la

${ }^{66}$ Marilú da Conceição, "O pesadelo de Cardoso. Analise do universo simbólico nos filmes de José Cardoso", en librillo acompañante al DVD 8mm: Anúncio, Pesadelo, Raizes (Moçambique: José Cardoso/ KUGOMA, 2014), p. 7.

67 Willet, El teatro de Bertolt Brecht, p. 256.

${ }^{68}$ Fernando Gonçalves Lavrador, Vértice, 291 (1967); citado en librillo acompañante al DVD $8 m m$, p. 3. escena, sino que aporta su acuidad particular; expone, reflexiona y proyecta significados propios y autónomos que dotan de una dimensión distinta a lo que transcurre.$^{69}$

Una secuencia corta, casi sumaria, da cuenta del rechazo de la empresa anunciante a la demanda de trabajo del hombre: unos pocos gestos, nada enfáticos, señalan al personaje la puerta de salida. En este momento, en este preciso punto de condensación de la implacable lógica social, se produce en la canción una de las frecuentes inversiones de texto y música entre secciones tan habituales en José Afonso, colocando el texto de la frase A sobre la música de la frase $\mathrm{B}$, una octava más aguda, y elevando la voz a pleno pulmón; véase Ejemplo 5.
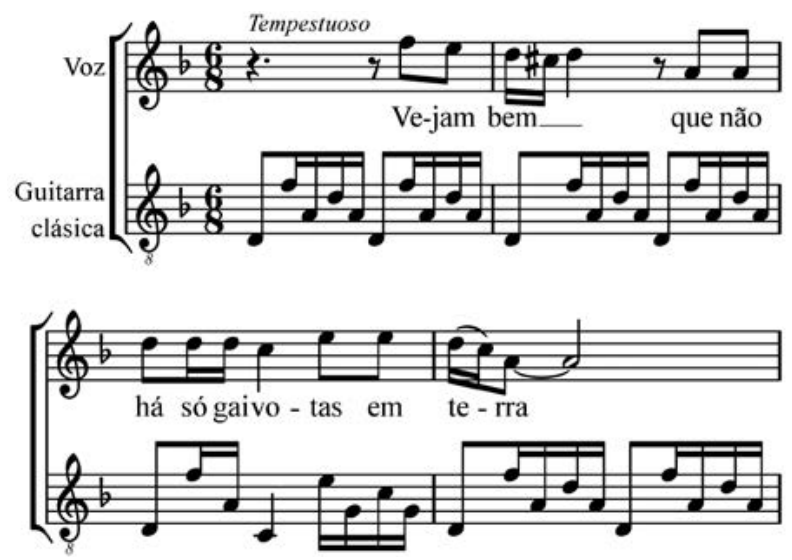

Ejemplo 5. José Afonso, "Vejam bem". Letra de la sección A con la música de la sección B.

La apelación a la atención del espectador ahora suena como un vendaval, como una auténtica orden y advertencia, casi como una amenaza, una premonición de una catástrofe o de un seísmo social y político: "Vejam bem / Que não há / Só gaivotas / Em terra / Quando um homem / Se põe / A pensar". ${ }^{70}$ Incidiendo sobre la cualidad de lo que se ve en cuanto escenario artificialmente montado para la exposición de un conflicto de clase, la canción se ha transformado en una llamada a la acción, no solo a la

69 Brecht, Escritos sobre el teatro, p. 251.

${ }^{70}$ Letra de "Vejam bem", en Cantares do andarilho (Orfeu, STAT 002, 1968). El dicho: "gaviotas en tierra, tempestad en el mar" se usa en Portugal para indicar la imposibilidad de hacerse a la mar debido al temporal. La asociación de ideas es clara: una actitud de reflexión crítica en un momento de tempestad social. 
contemplación. No se puede permanecer indiferente frente a lo que va a ocurrir. El desplazamiento del texto del tono simplemente introductorio, como de alzamiento de telón (en un 6/8 danzable en modo menor, que correspondía al registro expresivo de la música de la frase A), hacia un ambiente de tormenta como el que pronosticaba la naturaleza inquieta en el comienzo de la película produce una mutación tanto del mensaje de las imágenes como del estado de ánimo de quien escucha, al no estar la acción todavía desarrollada ni resuelta. La inquietud sube de tono. La canción actúa como un presagio o profecía anticipada de una conclusión completamente abierta resultado de una triple superposición de montajes: el propiamente fílmico, el inherente a la canción y el resultante de la fecundación mutua de canción y cine.

En el interior de la canción existen también una serie de mecanismos de ajuste y reajuste entre niveles dispares, no solo debido al juego de recolocación entre música y texto arriba descrito, sino, y de forma más sutil, al efecto de superposición de un patrón rítmico-melódico de clara raigambre popular con el acompañamiento de la guitarra clásica de Rui Pato. Obsérvese la insistencia de la guitarra destacando en un pequeño contrapunto el motivo de quinta transmisor del toque de atención al espectador. En otras palabras: montaje sintáctico que aprovecha los planos espaciales de los constituyentes musicales junto con montaje a partir de campos semánticos alejados; son connotaciones asociadas a procedimientos de la tradición culta en paralelo a otras provenientes de la tradición oral.

O Anúncio fue presentado por primera vez en Beira (Mozambique) en el Festival de Cine de amadores el 22 de agosto de 1966; A excepção e a regra se estrenó en la misma ciudad tan solo un día después. ${ }^{71}$ En el título e intención de "Vejam bem" resuena poderosamente el ímpetu didáctico de ese coro de actores que al principio de la pieza teatral lanza su advertencia al público: "Observem com atenção" (Beträchtet genau). Como en un coro griego, la exhortación funciona al mismo tiempo como voz colectiva que desentraña el sentido de la parábola y como distancia hacia la acción. De ahí que la canción de José Afonso traslade esa misma duplicidad funcional a su pa-

71 Álvaro Simões, librillo acompañante al DVD $8 m m$, p. 2. Entrada personal en su página de Facebook (12 de febrero de 2015): https://www.facebook.com/alvaro.simoes.790/posts/801 449449908190:0; consultado el 6 de febrero de 2020. pel en la dialéctica palabra lírica-voz-música, un relato montado con imágenes que se suceden. $\mathrm{Al}$ igual que en el teatro, en definitiva lo que la canción hace surgir de la película es lo mismo que Brecht pretende para sus obras: que no consideremos normales los comportamientos y las consecuencias sociales derivados de la brutalidad de la sociedad de clases, que los veamos extraños.

Hemos dejado para el final un aspecto, aparentemente nada brechtiano de la canción: la profunda empatía que Afonso siente por el personaje; la constancia de que su sufrimiento es también nuestro sufrimiento. Pero la contradicción entre extrañamiento y emoción es solo producto de una lectura reductora de las propuestas de Brecht. Didi-Huberman muestra con nitidez cómo la sustancia misma de la obra de Brecht estriba en todo un catálogo de situaciones de dolor humano y está guiada por lo que Hannah Arendt identifica como el gestus de la compasión. Distanciamiento y pathos están condenados siempre a ser vecinos. Lo que debe resultar de la contemplación de la injusticia no es una ausencia congelada de emoción, sino la certeza de que "toda piedad es engañosa" si no sabe cambiarse en "roja ira". ${ }^{72}$ No creo estar lejos de la verdad si afirmo que ese fue uno de los principios fundamentales que guiaron toda la acción estética y política de José Afonso.

\section{CONCLUSIÓN}

Aproximarse a la obra de José Afonso desde un único ángulo o punto de vista puede resultar estéril dada la complejidad, extensión, ambición y diversidad de planteamientos y resultados estilísticos que la recorren. No obstante, si enfocamos la mirada sobre ese momento crucial para el desarrollo artístico del cantautor que es su estancia en Mozambique entre 1964 y 1967, salta a primer plano la importancia de su encuentro con la obra de Bertolt Brecht para fijar un marco creativo que se ampliará de ahí en adelante como contexto teórico y práctico desde el que entender mucha de su producción. En este sentido, José Afonso lleva al terreno musical popular portugués la reivindicación de Brecht como modelo de intervención cultural que impregna la oposición socialista a la dictadura portuguesa desde principios de los años cincuenta del siglo XX. De este modo, es posible identificar tanto en sus prácticas compositivas como interpretativas una apropiación consciente de las concepciones brechtianas. Esa

72 Didi-Huberman, Cuando las imágenes, pp. 153-158. 
apropiación concierne no solo al papel social y político del músico y su música en la ruptura del monolítico orden cultural salazarista, sino, en una dimensión intrínsecamente estética, a la propia utilización de voces cronológica y estilísticamente múltiples para ensamblar artefactos de gran poder expresivo y movilizador.

En el terreno de las actitudes ante público y sociedad, lo explícitamente brechtiano aparece en la puesta en escena del gesto social haciendo la música que reclamaba Brecht, con la búsqueda constante de fórmulas enraizadas en tradiciones antiguas, insurgentes o populares, de cara a crear nuevas estructuras narrativas con "ruinas y fragmentos" desprovistos ahora de sus excrecencias subjetivistas y conservadoras; lírica y épica se funden en formas mixtas entre lo refinado y cotidiano con la pretensión de desplazar al oyente de un adormecimiento confortable a una posición de reflexión crítica ante las contradicciones sociales.

Una vez puesto el microscopio sobre el armazón lingüístico, retórico y significativo de las canciones y, particularmente, sobre las canciones que usan a Brecht como materia prima, lo que se aprecia es la densidad de significaciones y relaciones existentes entre los diferentes estratos literario-musical-interpretativos al servicio de los propósitos citados. Escuchamos el resultado de una manipulación formal, engañosa en la aparente direccionalidad y sencillez con la que nos afectan sus mensajes. Como hemos observado, es la flexibilidad somática con la que la voz hace suyas otras voces lejanas materializadas en la retórica musical, la que le confiere cuerpo y convocatoria emocional al montaje abriendo sus virtualidades significantes. El montaje cobra cuerpo en el gesto de la voz. El gestus brechtiano desplaza la emoción desde la compasión hacia la indignación y la llamada a la acción como hemos comprobado en las tres canciones analizadas. Esto es particularmente patente en la última de ellas: "Vejam bem". Al corresponderse y desajustarse el flujo de la canción y del film, emergen sus respectivas condiciones de montajes temporales que fuerzan, a la manera brechtiana, a una toma de posición según la terminología de Didi-Huberman: posición de la canción que llama violentamente a considerar extraño e inadmisible lo que se ve; posición de las imágenes removidas de su sitio por esas otras imágenes que brotan fraccionadas de la canción; y posición del que escucha, obligado a situarse críticamente ante la simultaneidad dispar, aunque ideológicamente consistente, de lo que ve y oye e impulsado a moverse políticamente por ello.
¿Cómo situar entonces estos productos culturales y situarnos frente a ellos? No cabe otra manera para evaluar su eficacia y su intensidad comunicativa que destacar esa combinación de juego y reflexión de la forma sobre sí misma, de llamada de atención y revelación en la arquitectura poliédrica de sus mimbres poético-musicales del entramado que sustenta las más crueles contradicciones sociales, teñida sin embargo, no pocas veces, de humor. Es la configuración de una manera de intervenir estética y políticamente mediante la canción en la cultura portuguesa sometida al fascismo, absolutamente moderna y absolutamente popular, José Afonso de la mano de Brecht y Brecht perviviendo en el compromiso estético de José Afonso.

\section{APÉNDICE}

\section{Revisión crítica de literatura seleccionada sobre José Afonso}

Nos parece adecuado, a modo de colofón, dedicar algún espacio a comentar la literatura editada sobre José Afonso y ofrecer una bibliografía seleccionada. En consonancia con la magnitud icónica del personaje, se ha vertido mucha tinta sobre su figura. La inmensa mayoría de las publicaciones son de carácter biográfico o periodístico, escaseando, sorprendentemente, los trabajos académicos y siendo aún más raros los análisis técnicos de sus canciones que pudieran dar cuenta de su calidad específicamente musical. Para evitar cargar el texto innecesariamente, todas las referencias son anotadas en detalle en la lista bibliográfica que se enumera al final.

Desde una perspectiva biográfica son especialmente notables el libro de su hermano João Afonso dos Santos, José Afonso. Um olhar fraterno (2002), tanto por la riqueza de información de primera mano cuanto por la sutileza y profundidad de los comentarios sociales, políticos, culturales e incluso sobre los aspectos musicales de la interpretación y las canciones. Por otra parte, Zeca Afonso. Livra-te do medo (2014), de José A. Salvador, es una versión corregida y aumentada de los anteriores trabajos de este autor, con diversidad de enfoques sobre su trayectoria y actividad creativa, basados en largas entrevistas personales con el músico. As voltas de un andarilho (2009) de Viriato Teles y las publicaciones de José Viale Moutinho en la década de los 70 son también imprescindibles para conocer la personalidad y el quehacer de Afonso. De Moutinho es la primera monografía en español, José Afonso, publicada por edi- 
ciones Júcar en 1975 en la serie Los Juglares. Para el período universitario de la vida del cantautor son jugosos aunque irregulares José Afonso: Da boêmia Coimbrã à fraternidade utópica (1929-2009) (2009) de Jorge Cravo y Zeca Afonso antes do mito (2000) de António dos Santos e Silva. De reciente aparición (2019) es un texto de Avelino Tavares sobre los conciertos en vivo de José Afonso que acompaña al lujoso estuche José Afonso ao vivo con la edición en vinilo y $\mathrm{CD}$ de este material inédito. Por último, José Afonso (2009) de Irene Flunsel Pimentel recopila una exhaustiva cantidad de material gráfico sobre él a modo de fotobiografía.

A caballo entre la divulgación y la academia, los trabajos de Mário Correia oscilan entre la amplia consideración de José Afonso en el marco de la evolución global de la música popular portuguesa entre las décadas de los años 50 y los 80 del siglo XX en su libro Música popular portuguesa: um ponto de partida (1984) y el tratamiento de aspectos particulares de su vida y obra en: As mulheres cantadas por José Afonso (2013); José Afonso andarilho nas Astúrias (2015) y A raiz genuina: a música tradicional na obra de José Afonso (2016).

En el plano estrictamente científico, hay que partir de la tesis pionera de Elfriede Engelmayer en 1985 para la Universidad de Viena, "Utopie und Vergangenheit: das Liedwerk des portugiesischen Sängers José Afonso", en la que cubre especialmente la dimensión moral e ideológica de la vertiente literaria de las canciones en el contexto de la situación portuguesa pre y post revolucionaria. Este estudio se complementa posteriormente con José Afonso, Poeta (1999) y la que es hasta la fecha la edición más completa de los textos poéticos de José Afonso (no solo los de las canciones), José Afonso. Textos e canções (2000).

Por su rigor metodológico y por su solidez teórica hay que mencionar el estudio que Maria de São José Côrte-Real dedica a José Afonso en su tesis de la Universidad de Columbia "Cultural Policy and Musical Expression in Lisbon in the Transition from Dictatorship to Democracy (1960s-1980s)" (2001). De esta autora es también el artículo sobre el cantautor en el primer volumen de la Enciclopédia da música em Portugal no século XX (2010). Entre otras tesis doctorales en torno a Afonso, destacamos por la particularidad del tema que aborda, "Rekonstruktion der Poetik des portugiesischen Dichters und Liedermachers José Afonso" (2011), del profesor de la Universidad de Colonia Alexandre Pereira Martins, donde se presenta una taxonomía estilística y temática de la creación poética de José Afonso. Menos interés tiene a nuestro juicio “La 'Canção de intervenção' e l'opera lirico-musicale di José Afonso" (1998), de Nicoletta Nanni en Bolonia. Por otra parte, la antología de canciones Eh Zeca Afonso! Lieder und Texte aus Portugal, editada por Heidi Bergmann (1980), contiene atinados e iluminadores comentarios sobre las canciones.

Últimamente, y dentro del interés del área de etnomusicología de la Universidade Nova de Lisboa por los estudios culturales en torno a la canción popular, se han producido dos trabajos en los cuales es central el nombre de José Afonso, si bien en el contexto del papel de la transformación de los medios de producción fonográficos para el surgimiento de una nueva tipología de canción socio-política. Se trata de: "'Nós humanizámos a indústria' reconfiguração da produção fonográfica e musical em Portugal na década de 60" (2009) de Leonor Losa; y "Discos na luta: a canção de protesto na producção fonográfica em Portugal nas décadas de 1960 e 1970" de José Hugo Pires Castro (2012). A su vez Maria Inês Nogueira dedicó su tesis de maestría "A música tradicional na obra de José Afonso" (2009) a esta faceta de su producción.

\section{Bibliografía sobre José Afonso}

Afonso dos Santos, João. José Afonso. Um olhar fraterno. Lisboa: Caminho, 2002.

Bergmann, Heidi, Dieter Offenhäusser, Carmen Barros y Michael, eds. Eh Zeca Afonso! Lieder und Texte aus Portugal. Freiburg: Druckwerkstatt im Grün, 1980.

Correia, Mario. A raiz genuína, a música tradicional na obra de José Afonso. Centro de Música Tradicional Sons da Terra, 2016.

- Música popular portuguesa: um ponto de partida. Coimbra: MC-Mundo da Canção/Centelha, 1984.

_. As mulheres cantadas por José Afonso. Sendim: Sons da Terra, 2013.

—_ José Afonso andarilho nas Astúrias. Centro de Música Tradicional Sons da Terra, 2015.

Côrte-Real, Maria de São José. "Cultural Policy and Musical Expression in Lisbon in the Transition from Dictatorship to Democracy (1960s-1980s)". Tesis doctoral, Ph.D., Columbia University, 2001.

_. "Sons de Abril: Estilos musicais e movimentos de intervenção político-cultural na Revolução de 1974". Revista Portuguesa de Musicologia, 6 (1996), pp. 141-71.

__. "Afonso, José”. En Enciclopédia da Música em Portugal no Século XX, 4 vols., dirigida por Salwa 
El-Shawan Castelo-Branco. Lisboa: Círculo de Leitores, 2010, vol. 1 A-Z, pp. 15-18.

Cravo, Jorge. José Afonso: da boêmia Coimbrã à fraternidade utópica (1929-2009). Coimbra: Câmara Municipal, 2009.

Dos Santos e Silva, António. Zeca Afonso antes do mito. Coimbra: Minerva, 2000.

Engelmayer, Elfriede. "Utopie und Vergangenheit. Das Liedwerk des portugiesischen Sängers José Afonso". Tesis doctoral, Universität Wien, 1985.

—. José Afonso, poeta. Lisboa: Ulmeiro, 1999.

- José Afonso. Textos e canções, $3^{\text {a }}$ edição revista. Lisboa: Relógio d'Água Editores, 2000.

Fanha, José y José Jorge Letria. José Afonso: o que faz falta. Uma memória plural. Porto: Campo das Letras, 2004.

Fiuza, Alexandre Felipe. "Representações do espaço africano na moderna canção popular portuguesa: o caso José Afonso". TriceVersa 2/1 (2008), pp. 15-35.

Flunsel Pimentel, Irene. José Afonso, editado por Joaquim Vieira. Fotobiografias século XX. Rio de Mouro: Círculo de Leitores, 2009.

Losa, Leonor. “'Nós humanizámos a indústria': reconfiguração da produção fonográfica e musical em Portugal na década de 60". Tesis de Máster, Universidade Nova de Lisboa, 2009.

Moutinho, José Viale. José Afonso. Porto: Livraria Paisagem, 1972.

- Memória do canto livre em Portugal. Lisboa: Editorial Futura, 1975.

Moutinho, José Viale (coord.). José Afonso. Textos e canções. Porto: Paisagem Editora, 1975.

Nanni, Nicoletta. “La 'Canção de intervenção' e l'opera lirico-musicale di José Afonso". Tesi di Laurea, Università degli Studi di Bologna, 1998.

Nogueira Igrejas Moreira, Maria Inês. "A música tradicional na obra de José Afonso". Tesis de Máster, Universidade Nova de Lisboa. Faculdade de Ciencias Sociais e Humanas, 2009.

Pereira Martins, Alexandre. "Rekonstruktion der Poetik des portugiesischen Dichters und Liedermachers José Afonso (1929-1987)". Tesis doctoral, Ph.D, Colonia (Alemania), Universität zu Köln, 2011.

Pires Castro, José Hugo. "Discos na luta: a canção de protesto na producção fonográfica em Portugal nas décadas de 1960 e 1970". Tesis de Máster, Universidade Nova de Lisboa, 2012.

Raposo, Eduardo M. Canto de intervenção, 1960-1974, $3^{\text {a }}$ edición. Lisboa: Público, 2007.
Saldanha, Ana. "Representações e transformações estéticas e ideológicas da canção-composição de intervenção. Fernando Lopes-Graça. José Afonso, Adriano Correia de Oliveira e Jorge Peixinho". En Estudos da Ail em Literatura, História e Cultura Portuguesas, editado por Elías J. Torres Feijó et al. Santiago de Compostela y Coimbra: Associação Internacional de Lusitanistas, 2016, pp. 57-63.

Salvador, José A. Livra-te do medo: Estorias e andanças do Zeca Afonso. Lisboa: A Regra do Jogo, 1984.

- José Afonso, o rosto da utopia, $4^{\mathrm{a}}$ edición. Porto: Edições Afrontamento, 2006.

—. Zeca Afonso. Livra-te do medo. Lisboa: Porto Editora, 2014.

Teles, Viriato. As voltas de um andarilho. Fragmentos da vida e obra de José Afonso. Lisboa: Assírio \& Alvim, 2009.

\section{BIBLIOGRAFÍA CITADA}

Afonso dos Santos, João. José Afonso. Um olhar fraterno. Lisboa: Caminho, 2002.

—_. "Lá no Xipangara". AJA. Revista da Associação José Afonso, 7 (1993), p. 30.

Afonso, José. Cantares. Lisboa: Associação de Estudantes do IST, 1968.

—. "Carta desde Beira de 03 de enero de 1967". Archivo del Centro de Documentação 25 de Abril en Coimbra, Espólio Rui Pato, Correspondência Zeca-Albano de Rocha Pato, pasta XLVI, n 29.

—. "Carta desde Beira de 25 de marzo de 1967". Archivo del Centro de Documentação 25 de Abril en Coimbra, Espólio Rui Pato, Correspondência Zeca-Albano de Rocha Pato, pasta XLVI, n 30.

_. "Carta desde Faro de 20 de julio 1964". Archivo del Centro de Documentação 25 de Abril en Coimbra, Espólio Rui Pato, Correspondência Zeca-Albano de Rocha Pato, pasta XLVI, $\mathrm{n}^{\circ} 14$.

- Cantares do andarilho. Disco de vinilo. Orfeu STAT 002 (1968).

_. Eu vou ser como a toupeira. Disco de vinilo. Orfeu STAT 016 (1972).

. Coro dos tribunais. Disco de vinilo. Orfeu STAT 027 (1974).

Berendse, Sabine y Clemens, Paul, eds. Brecht, Music and Culture. Hanns Eisler in Conversation with Hans Bunge. London: Bloomsbury, 2014.

ANUARIO MUSICAL, N. ${ }^{\circ}$ 75, enero-diciembre 2020, 117-137. ISSN: 0211-3538 https://doi.org/10.3989/anuariomusical.2020.75.06 
Brecht, Bertolt. Schriften zur Kunst und Literatur, 3 vols. Frankfurt: Suhrkamp Verlag, 1967.

- Escritos sobre teatro, traducción de Genoveva Dieterich. Barcelona: Alba editorial, 2004.

Cardoso dos Santos, José. 8mm: Anúncio, Pesadelo, Raizes. DVD. Kugoma, Short Films Forum Mozambique, 2014.

Cascudo, Teresa. "Fernando Lopes-Graça e a configuração do modernismo em Portugal através da obra de Fernando Lopes-Graça". En Fernando Lopes-Graça. Madrid: Atelier, 2010, pp. 29-64.

Castilho Pais, Carlos. "Apontamentos sobre a maldita censura aos poemas de Brecht". En https://carloscastilhopais.files.wordpress.com/2010/01/apontamentos20brecht

Costa, Belino. "Conservar a cultura não é ser conservador". Entrevista a José Afonso. En Se7e (25 de noviembre de 1981).

Cuadrado, Perfecto. "Situación histórica de la poesía surrealista portuguesa 1: El Surrealismo portugués en el contexto de la literatura portuguesa contemporánea". Mayurqa. Revista del Departament de Ciències Històriques i Teoria de les Arts, 19/2 (1979), pp. 93-126.

- "Situación histórica de la poesía surrealista portuguesa 2: Surrealismo, movimiento surrealista y poesía surrealista en Portugal". Caligrama. Revista insular de filología, 1/1 (1984), pp. 91-135.

Da Conceição, Marilú. "O Pesadelo de Cardoso. Analise do universo simbólico nos filmes de José Cardoso". En librillo acompañante al DVD 8mm: Anúncio, Pesadelo, Raizes Kugoma, Short Films Forum Mozambique, 2014, pp. 7-10.

Didi-Huberman, Georges. Cuando las imágenes toman posición. Madrid: Antonio Machado libros, 2008.

Dos Santos e Silva, António. Zeca Afonso antes do mito. Coimbra: Minerva, 2000.

El-Shawan Castelo-Branco, Salwa. "Introducção". En Enciclopédia da música em Portugal no século XX, 4 vols., dirigida por Salwa El-Shawan Castelo-Branco. Lisboa: Círculo de Leitores, 2010, vol. 1, pp. i-vii.

Frith, Simon. Taking Popular Music Seriously. Londres y Nueva York: Ashgate, 2007.

Frota, Gonçalo. "Deixou de haver ética e sangue na criação artística. Entrevista a José Mário Branco". En Público (28/11/2017). https://www.publico. pt/2017/11/28/culturaipsilon/entrevista/jose-mario- branco-deixou-de-haver-etica-e-sangue-na-criaçaoartistica-1794087; consultado el 19 de noviembre de 2019.

Hall, Stuart. "Notes on Deconstructing 'the Popular'". En Cultural Theory and Popular Culture: A Reader, editado por John Storey. Pearson: Prentice Hall, 1998, pp. 442-53.

Holub, Renate. Antonio Gramsci. Beyond Marxism and Postmodernism. Abingdon: Routledge, 2014.

Iglesias Mira, Antonio. Castelao e a sua época na Coimbra de 1969. Tesis de Máster. Faro: Universidade do Algarve, 2011, anexos 7 y 8.

—_ "O goberno portugués contra Castelao: a aventura galega do CITAC". Abriu: estudos de textualidade do Brasil, Galicia e Portugal, 4 (2015), pp. 61-75.

Jameson, Fredric. "Afterword". En Aesthetics \& Politics. Debates between Bloch, Lukács, Brecht, Benjamin, Adorno, editado por Ronald Taylor. Londres: Verso, 1980, pp. 196-213.

Kramer, Lawrence. Musical Meaning. Toward a Critical History. Berkeley: University of California Press, 2002.

Livio, Tito. "Três albuns importantes. Uma canção significante". Mundo da Canção, 34 (1973), pp. 6-8.

Lunn, Eugene. Marxism \& Modernism. An Historical Study of Lukács, Brecht, Benjamin, and Adorno. Berkeley: University of California Press, 1982.

Manuel, Peter. Cassette Culture: Popular Music and Technology in North India. Chicago: The University of Chicago Press, 1993.

Middleton, Richard. Studying Popular Music. Philadelphia: Open University Press, 1990.

Paddison, Max. "The Critique Criticised: Adorno and Popular Song". Popular Music, 2 (1982), pp. 201-18.

Pereira Martins, Alexandre. "Rekonstruktion der Poetik des portugiesischen Dichters und Liedermachers José Afonso (1929-1987)". Tesis doctoral, Ph.D., Colonia (Alemania), Universität zu Köln, 2011.

Rebello, Luiz Francisco. Teatro moderno: caminhos e figuras. Lisboa: Prelo, 1964.

Rodrigues, Márcia Regina. Traços épico-brechtianos na dramaturgia portuguesa: O render dos héroes, de Cardoso Pires, e Felizmente há luar!, de Sttau Monteiro. São Paulo: Cultura Acadêmica, 2010.

Sá Nogueira, Teresa. "Cinema moçambicano". Tempo [Mozambique] (17/08/1986).

Salomé, Vitorino. Entrevista concedida al autor del artículo. Évora (19/08/2019). 
Salvador, José António. Zeca Afonso. Livra-te do medo. Lisboa: Porto Editora, 2014.

Simões, Álvaro. Entrada personal en su página de Facebook (12 de febrero de 2015). En https://www.facebook. com/alvaro.simoes.790/posts/801449449908190:0; consultado el 6 de febrero de 2020.

Taylor, Ronald, ed. Aesthetics \& Politics. Debates between Bloch, Lukács, Brecht, Benjamin, Adorno. Londres: Verso, 1980.

Teles, Viriato. As voltas de um andarilho. Fragmentos da vida e obra de José Afonso. Lisboa: Assírio \& Alvim, 2009.
Vieira de Carvalho, Mário. "Between Political Engagement and Aesthetic Autonomy: Fernando Lopes-Graça's Dialectical Approach to Music and Politics". Twentieh-Century Music, 8/2 (2011), pp. 175-202.

Willet, John. El teatro de Bertolt Brecht. Un estudio en ocho aspectos. Buenos Aires: Fabril, 1964.

Recibido: 14/04/2020

Aceptado: 09/08/2020 